\title{
Clitic doubling and pure agreement person features
}

\section{Redobro de clítico e concordância pura de traços de pessoa}

\author{
Ricardo Machado-Rocha \\ IFMG \\ ricardomachado252@gmail.com \\ Jânia Martins Ramos \\ UFMG \\ jania.ramos@gmail.com
}

\begin{abstract}
In this paper, we analyze accusative clitic doubling constructions in dialectal non-standard Brazilian Portuguese. Within the Minimalism Framework, we explain very peculiar aspects of the doubled structures in this language, namely the fact that they occur only for $1^{\text {st }}$ and $2^{\text {nd }}$ person pronouns and that they co-vary with single clitic structures and single strong pronoun structures. Our approach assumes that the clitics $m e$ and te are hosted by a dedicated functional projection and result from the checking of the sole person feature [speaker: \pm ]. Moreover, we show that, unlikely other cross-linguistic phenomena of pronominal doubling, Brazilian Portuguese Clitic Doubling neither yields (nor is a result of) any interpretive effect, but rather is an instance of a pure agreement chain. This leads us to advocate both contra the standard Minimalist Program, and for the validity of the conceptual postulation of AgrP, as a condition on well-formedness of certain structures.
\end{abstract}

Keywords: clitic doubling; agreement; person features; Brazilian Portuguese. 
Resumo: Neste artigo, analisamos construções de redobro de clítico acusativo no português brasileiro dialetal não padrão. Tomando o quadro teórico do Minimalismo, nós explicamos aspectos bastante peculiares das estruturas redobradas nessa língua, quais sejam: o fato de que elas ocorrem apenas para pronomes de $1 .^{\mathrm{a}} \mathrm{e} 2$. $^{\mathrm{a}}$ pessoa e o fato de que elas covariam com estruturas com apenas o clítico e estruturas com apenas o pronome forte. Nossa proposta assume que os clíticos me e te são hospedados por uma projeção funcional específica e resultam da checagem de um único traço de pessoa [speaker: \pm ]. Além disso, nós mostramos que, diferentemente de outros fenômenos de redobramento pronominal em outras línguas, o redobro de clítico no português brasileiro não resulta em, nem é consequência de, nenhum efeito interpretativo, mas ao contrário é um caso de cadeia de concordância pura. Isso nos leva a defender tanto a ideia contrária ao Programa Minimalista padrão quanto a validade do conceito teórico AgrP como uma condição de boa formação de certas estruturas.

Palavras-chave: redobro de clítico; concordância; traços de pessoa; português brasileiro.

Recebido em 30 de março de 2015. Aprovado em 19 de agosto de 2015.

\section{Introduction}

Clitic doubling (CD) is a structure in which a clitic co-occurs with a full DP or strong pronoun, forming a type of discontinuous constituent with it. This reduplication phenomenon is attested in a large number of languages (for a review, see ANAGNOSTOPOULOU, 2006).

(1)

Juan $\underline{\text { la }} \quad$ conoce a $\underline{\text { ella. }}$ (Spanish)

John $\underline{\text { CL-ACC knows a her }}$

(“John knows her.")

(TORREGO, 1995, p. 403). 
(2)

$\underline{T u}$ to edhosa tu Jani to vivlio. (Greek)

Cl-GEN $\boldsymbol{C l}$ - $A C C$ gave1SG the Janis- GEN the book- $A C C$

("I gave John the book.")

(ANAGNOSTOPOULOU, 2006, p. 545).

The general research questions about CD from the GB model until pre-Minimalism works were related to (i) the parameters regulating the occurrence of CD cross-linguistically. In other words, many investigations were concerned about why CD occurs, for instance, in Spanish and Greek, but not in French (JAEGLI, 1982, 1986; BORER, 1984, among others); and (ii) what are the "special" structures licensing CD. One main answer was the so-called Kayne's Generalization (attributed to KAYNE in JAEGLI, 1982, p. 20) apud Anagnostopoulou (2006, p. 521), according to which, clitic doubling would occur only when a DP was preceded by a special preposition, as in (1) for Spanish, in which the DP is preceded by the preposition $a$. However it did not take too long for this generalization to be challenged. The example from Greek in (2) shows that doubling is possible in the absence of a preposition. Actually the presence of a preposition in Greek prevents the occurrence of the doubled structure:

(3)

* $\underline{\boldsymbol{T u}}$ edhosa to vivlio $\underline{\mathbf{s}}$-ton Jani.

Cl-GEN gave1SG the book-ACC Prep- the Janis

("I gave John the book.")

(ANAGNOSTOPOULOU, 2006, p. 546).

Even for Spanish, Suñer (1988) showed that it is possible to find doubling without a preposition:

(4)

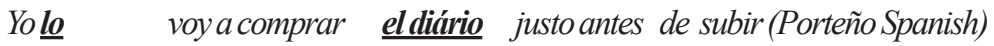

I CL-ACC will Prep buy the newspaper just before of going up

("I will buy the newspaper just before going up.")

(SUÑER, 1988, p. 400). 
Most of the literature focused attention on $3^{\text {rd }}$ person CD. $1^{\text {st }}$ and $2^{\text {nd }}$ person CD is not largely analyzed (cf. JAEGLI, 1982, 1986; BORER, 1984; SUÑER, 1988; DOBROVIE-SORIN, 1990; SPORTICHE, 1996; ANAGNOSTOPOULOU 1994, 2003, 2006; URIAGEREKA, 1995; TORREGO, 1998; among many others).

When compared to what is shown and argued in the literature, dialectal Brazilian Portuguese (BP $)^{1}$ clitic doubling is curious in a number of aspects.

To start with, $\mathrm{CD}$ in BP occurs only with $1^{\text {st }}$ and $2^{\text {nd }}$ person pronouns.

(5)

Brazilian Portuguese clitic doubling

$1^{\text {st }}$ person pronouns

a. Ele $\underline{\boldsymbol{m e}}$ ajuda $\underline{\mathrm{eu}}$

He 1P-CL helps $\underline{\mathbf{I}}$

("He helps me.")

b. tinha cinco médico lá $\underline{\text { me }}$ oinano $\underline{\text { eu }}$ assim $^{2}$

Had five doctor there 1PCL looking $\underline{I}$ this way

("There were five doctors there looking at the like this")

$2^{\text {nd }}$ person pronouns

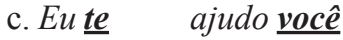

I 2P-CL help you

("I help you.")

d. se cê uma hora acha um que $\underline{\text { te }}$ acerta ocê $\underline{\hat{y}}^{3}$

if you one hour finds one that 2PCL hits you

("if sometime you find someone that hits you...")

\footnotetext{
${ }^{1}$ The data considered in this work are mainly comprised by non-standard dialectal speech from the region of Minas Gerais. The main sources are Ramos (2010), from which we used only spoken data, and Machado-Rocha (2013), comprised exclusively of spoken data. In addition to that, we also used some introspection data, which reflect very common structures for the authors' dialect.

${ }^{2}$ RAMOS (2010).

${ }^{3}$ Idem.
} 
In the history of Portuguese, and also in current standard BP writing, we can find pronoun reduplication even for $3^{\text {rd }}$ person pronouns. But these constructions are structurally different from what we are analyzing in present dialectal BP. Consider examples (6):

(6)

a. Medieval Portuguese ( $13^{\text {th }}$ century)

$e$ chagarom-no a el de muitas chagas

and injured-3PCL to him of many injuries

("and they have caused him many wounds"

(CASTILHO, 2005, p. 33).

b. Current standard Brazilian Portuguese

Viu-me a mim (e não a ele).

Saw-1PCL to me (and not to him)

("He saw ME, not him.")

(CASTILHO, 2005, p. 35).

In standard writing, the doubled structure always yields contrastive focus, as can be seen in (6.b). This stylistic contrastive doubling always occurs with a strong oblique pronoun, preceded by the preposition $a$, and the clitic is normally enclitic. On the other hand, current Brazilian Portuguese is essentially proclitic. The structures in (5) do not allow any type of contrastive reading. Moreover, the clitic doubling structure we are analyzing is basically comprised by adjacent CL-V-Strong default pronoun, obligatorily in this order.

Although $3^{\text {rd }}$ person clitics are still present in standard writing and we cannot point out precisely the dialects of BP in which these pronouns are completely lost in speech, it is widely accepted that such forms are used in spoken language only as a result of education and in very formal registers (KATO, 2005; GALVES 2001; MAGALHÃES, 2000; CORRÊA, 1991). Furthermore, in the dialect under investigation, the doubled structure with $3^{\text {rd }}$ person clitic is ungrammatical. The general resort for realizing a $3^{\text {rd }}$ person pronominal object in this dialect is by means of an overt strong pronoun, acceptable for all speakers, with no stigma. The single structure with a clitic is highly formal and may yield different grades of unacceptability, depending on the speaker's level of education and access to the formal variety. 
(7)

*Eu $\underline{\text { o }}$ ajudo $\underline{\text { ele }}$.

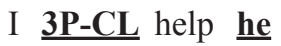

("I help him.")

(8)

Eu $\underline{\boldsymbol{o}}$ ajudo.

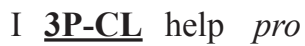

("I help him.")

(9)

Eu ajudo ele.

I help $\underline{\text { he }}$

("I help him.")

A second curious aspect of BP CD is that it is optional. ${ }^{4}$ Jaeggli (1982) shows contexts in Spanish where clitic doubling or simple cliticization are obligatory. The environments in question are inalienable possession constructions and constructions with strong object pronouns:

Inalienable possession constructions

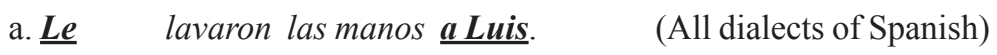

Cl-DAT washed the hands a Luis

("They washed Luis's hands.")

b. Le lavaron las manos.

c. *Lavaron las manos a Luis.

${ }^{4}$ See section 4.1 for the definition of optionality we employ here, based on McCloskey (1996). 
(11)

Strong pronouns
a. *Vimos a él.
(All dialects of Spanish)
Saw-we a him
("We saw him.")
b. $\underline{\boldsymbol{L} \boldsymbol{O}}$ vimos.
Cl-ACC saw-we
("We saw him.")
c. $\underline{\text { Lo }}$ vimos $\underline{\text { a él. }}$.
Cl-ACC saw-we a him
("We saw him.")

BP seems to have no obligatory context for CD or simple cliticization, and either the clitic or the object can be absent, but not both, unless the null object is discourse licensed:
a. Eute ajudo você
I $\underline{\mathbf{2 P}-C L}$ help you
b. Eu ajudo você
c. Eute ajudo
("I help you.")
I help you
I $\underline{\text { PP-CL help }}$
d. * Eu ajudo (Unless it is discourse licensed.)
I help

As for the Kayne Generalization, BP accusative CD occurs without a preposition, as can be seen in 5, which is again, along with other cross-linguistic evidence, a challenge for previous analyses.

Dialectal BP data pose many theoretical challenges. In this paper, we want to address mainly two points:

i. The optionality of CD in BP. Our attempt is to draft an account for the fact that the doubled structure may covary with the single structures, while other languages, like Spanish, have contexts of obligatory doubling.

ii. The fact that dialectal non-standard BP cliticization does not occur for $3^{\text {rd }}$ person, but only for $1^{\text {st }}$ and $2^{\text {nd }}$ person pronouns. 
As shown above, the "free" optionality of CD in BP sounds as an oddity, when compared to most analyses presented in the literature. Because of this, we have attempted to find some interpretive reasons for the occurrence of CD in BP. We show these attempts in section 2.1 and 2.2.

The article is organized as follows: in section 2, we review the literature that claims for interpretive effects in clitic doubling structures and show a previous attempt to find such effects in BP CL; section 3 recalls theoretical backgrounds for this analysis; section 4 is a change in the direction of the analysis and new backgrounds are called into scene; in section 5, we present a new hypothesis and its application for BP data; ${ }^{5}$ section 6 sums up the discussions and conclusions.

\section{Clitic doubling and interpretive effects in BP CD}

Virtually all the literature about $\mathrm{CD}$ claims for some interpretive effect of doubled structures. Early GB studies (e.g. JAEGGLI (1982, 1986); BORER (1984) have argued that the doubling pronoun would guarantee (or make it explicit) that the doubled DP was definite or specific. In these cases, the doubled DP should obligatorily be preceded by a special preposition ( $a$ in Spanish, shel in Hebrew, pe in Romanian). For instance, (1') would be ungrammatical, because the clitic is doubling an indefinite DP.



Suñer (1988), building on Borer's (1984) insights, assumed that direct object doubling in Spanish is limited to specific NPs and also argued that animacy effects are involved in pronoun reduplication phenomena. Sportiche (1996) proposes that clitics license specificity on their associates. Indirect object clitic heads are treated as indirect

\footnotetext{
${ }^{5}$ In this paper, we will analyze only accusative doubled structures with the clitics me and te. Structures with datives, possessives and obliques would make the field of investigation too wide for the purposes of this paper, and then we are leaving these constructions for future inquiries.
} 
object agreement markers, since they do not yield specificity effects. Uriagereka (1995), treating accusative clitics as determiners (the Big DP Hypothesis), assumes that accusative clitics in all languages undergo movement to a functional domain and that they are necessarily specific. Bleam (1999) assumes animacy restrictions on direct object doubling. Torrego (1998) argues that clitics must be specific (or definite). Moreover, she also identifies a further range of semantic properties of the predicate as a whole that determine the presence of $a$ as a marker of the doubled direct object in Spanish; these include telicity, agentivity and affectedness. These properties determine the presence of $a$ independently of clitic doubling, but they impose conditions on the possibility of clitic doubling. Roberts (2010) follows Uriagereka (1995) in assuming that accusative clitics must be specific.

All these analyses sound as a strong suggestion that BP clitics (and clitic doubling structures) would also be related to interpretive effects such as specificity or definiteness. Finding these kind of effects was one of our first attempts, which we describe in the next section.

\section{Clitic doubling as a person-specific structure}

Machado-Rocha $(2010,2011)$ suggested that the doubled structure would guarantee that the reference of the argument pronoun would be specific (non-generic). More specifically, it is claimed that the $1^{\text {st }}$ and $2^{\text {nd }}$ person strong pronouns $e u$ and você, in single structures, would allow an ambiguous reading, between generic and non-generic, whereas the doubled structures $\mathrm{Cl}-\mathrm{V}$-Strong pronoun would be necessarily non-generic.

(17)

a. Single strong pronoun structure: ambiguous reading between generic and non-generic

E quando você tenta sair dessa vida, ninguém ajuda você não.

and when you try to go out of-this life nobody helps you not ("And when you/someone try to leave this bad behavior, nobody helps you/someone.") 
b. Doubled structure: unambiguous non-generic reading

E quando você tenta sair dessa vida, ninguém te ajuda você não.

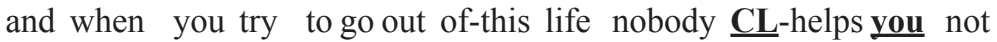
("And when you try to leave this bad behavior, nobody helps you.") (MACHADO-ROCHA 2010, p. 104).

In building that account, Machado-Rocha $(2010,2011)$ pointed out that $1^{\text {st }}$ and $2^{\text {nd }}$ person pronouns allow generic reading, whereas $3^{\text {rd }}$ person pronouns forbid it.

a. Hoje vê eufumandoum cigarro, amanhã pega ex experimentado coisa pior.

Today sees I smoking a cigarette tomorrow catches I trying thing worse

("Today people see me / someone smoking a cigarette, tomorrow they catch me / someone trying worse things.")

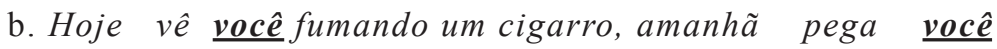
experimentado coisa pior.

Today sees you smoking a cigarette tomorrow catches you trying thing worse

("Today people see you / someone smoking a cigarette, tomorrow they catch you/someone trying worse things.")

c. Hoje vê ele fumando um cigarro, amanhã pega ele experimentado coisa pior.

Today sees he smoking a cigarette tomorrow catches $\underline{\text { he }}$ trying thing worse

("Today people see him smoking a cigarette, tomorrow they catch him trying worse things.")

As can be seen, (18.a) and (18.b) allow an ambiguous reading, and the generic interpretation is allowed. (18.c), on the other hand, is unambiguously non-generic, and the interpretation of this pronoun must

${ }^{6}$ These examples are an adaptation of some examples presented in Carvalho (2008). 
have a discourse antecedent or a deictic reference. As for $1^{\text {st }}$ and $2^{\text {nd }}$ person pronouns, no antecedent is required, and the deictic reference is bleached, when these pronouns figure in a generic construction. To make a generic context with $3^{\text {rd }}$ person pronoun, a pro is used, in a null object structure.

a. E você acha que empresa de telefone está preocupada em ajudar $\underline{\text { ele }}$ ? and you think that company of telephone is worried in help he ("And do you think that telephone companies are worried about helping him?)

(Obligatorily non-generic)

b. E você acha que empresa de telefone está preocupada em ajudar ?

and you think that company of telephone is worried in help pro ("And do you think that telephone companies are worried about helping anyone?)

(Generic reading allowed)

(MACHADO-ROCHA, 2010, p. 105).

Considering these differences and the fact that $3^{\text {rd }}$ person pronouns are underspecified for the speech-act features [speaker] and [addressee], Machado-Rocha $(2010,2011)$ concluded that the presence of the clitics $m e$ and $t e$, in doubled structures, would make the features [speaker] and [addressee] in the strong pronouns $e u$ and você unambiguously non-generic, in opposition to the ambiguous reading of the single strong pronoun structure. Therefore, there would be no $3^{\text {rd }}$ person doubled structure, because there is no [speaker] or [addressee] feature in these pronouns. To explain the single structure with clitics, it was argued that actually the clitic doubled a pro, in a Sportiche's (1996) fashion. 


\section{Clitic doubling, copy theory and parallel chains}

Another intuition in previous steps of this study was that BP $\mathrm{CD}$ would be due to non-deleted copies in chains, considering chains to be the result of copied/moved elements. In pursuing such an approach, Machado-Rocha $(2010,2011)$ adopted basically Chomsky (2005) Phase syntax and Nunes' (2011) developments for the Copy Theory.

The main attempt of those works was to try the theoretical possibility of analyzing clitic and strong pronoun, in doubled structures, as chains' links. The strong pronouns would be the chain's tail and the clitic would be the head. Normally, all the links of a chain are deleted, but the head.

Nunes (2011) explains that the head of a chain is the optimal candidate for being spelled-out, because it is the link which has the largest number of checked / valued features. Still according to him, a chain cannot exhibit more than one link with the same phonetic material, because the structure containing it could not be linearized. In some particular situations, however, the phonetic realization of more than one link of a chain would be possible. He then presents the structure in (20).

a. Structure sent to Spell-out:

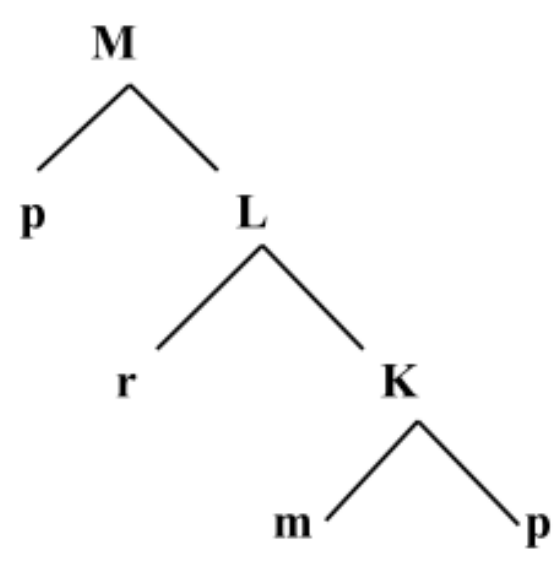


b. Fusion in the morphological component

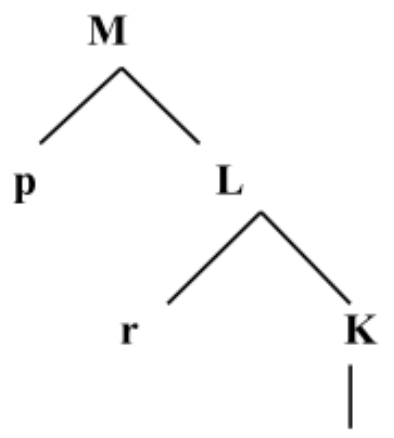

\section{\#mp\#}

Source: NUNES, 2011, p. 160.

Nunes remarks the presence of two copies of $p$ sent to Spell-out in (a). But in the Morphological Component, the terminals $p$ and $m$ are fused (in the sense of HALLE; MARANTZ, 1993), yielding the atomic terminal \#mp\# (or \#pm\#), with no internal structure accessible for further morphological or syntactic operations. For linearization purposes, $p, r$ and $\# m p \#$ do not represent a problem, since there are not two phonetically identical elements. In such line of reasoning, it is possible to realize two copies in a chain, provided that there are morphological reasons for that.

Considering these premises, Machado-Rocha (2010, 2011) took doubling clitic and strong pronoun to be morphologically distinct, phonetically realized links of a chain. He also considered that the clitic doubling structure would have to be accounted for in terms of parallel chains, as proposed in Chomsky (2005).

In the On Phases framework (CHOMSKY, 2005), syntactic operations are basically reduced to two kinds of Merge: the External Merge, which targets items in the Numeration; and Internal Merge, which takes syntactic objects present in the course of the derivation. Both types of Merge would check uninterpretable features, and thus fulfill the Full Interpretation Principle (FI).

Uninterpretable features are also considered to be of only two types: the Edge Features, which either activate the Selection of items from the Numeration or the copy of syntactic objects present in the course of the derivation; and the Agreement features, responsible for 
Agree operations, which can result both in copy/movement operations of whole elements or simply copy/movement of Formal Features, giving rise to long-distance Agree, as proposed before in Chomsky (1993, 1995).

Chomsky still proposes some modifications in what regards chain cyclicity. Previously, a same element in a chain could undergo multiple movements and form a chain with three or more links. Departing from this traditional view, and considering the copy approach, Chomsky $(2005$, p. 16) assumes that, when an element seems to move more than once, forming chains of the type A'-A-A, what is actually happening is the construction of distinct chains, starting from the same base element.

(21)

$\mathrm{C}\left[\mathrm{T}\left[\right.\right.$ who $\left[\mathrm{v}^{*}\right.$ [see John] $\left.\left.]\right]\right]$

who $_{i}\left[\mathrm{C}\left[\right.\right.$ who $\left.\left._{j}\left[\mathrm{~T}\left[\mathrm{who}_{k} \mathrm{v}^{*}[\mathrm{see} \mathrm{John}]\right]\right]\right]\right]$

who saw John

$\mathrm{C}[\mathrm{T}[\mathrm{v}$ [arrive who]]]

who $_{i}\left[\mathrm{C}\left[\right.\right.$ who $_{j}\left[\mathrm{~T}\left[\mathrm{v}\right.\right.$ [arrive $\left.\left.\left.\left.\left.\mathrm{who}_{k}\right]\right]\right]\right]\right]$

who arrived

Considering (21), Chomsky argues that in phase $v^{*}$, the agreement operation between $v^{*}$ and John values all uninterpretable features. In phase C, both Edge features and Agree features of C probe the goal who in Spec, $v^{*}$. The Agree features, inherited by $\mathrm{T}$ form $\mathrm{C}$, attract the probed element, that is, trigger a copy operation, to Spec-T, whereas the Edge features of $\mathrm{C}$ attract the same element (yielding a new copy operation) to Spec-C. The result of these double copy / movement operations is shown in (21.b). Chomsky highlights that one chain is built with the copies $\left\{w_{i}\right.$, who $\left._{k}\right\}$, and another with the copies $\left\{w_{h o} \mathrm{e} w_{h o}\right\}$, with no direct relation between $w h o_{i}$ and who. Thus, in (21.b) two A-chains are formed. The same reasoning applies to (22), in which two parallel chains are formed by the Agree features and the Edge feature of $\mathrm{C}$.

Now, with this background at hand, let us consider first that, in a clitic doubling structure, a strong pronoun and a clitic could be the realization of different links of a same chain (23): 
(23)

Eu te ajudo você

[T [te $[v$ ajudo [ você $]]]$

("I help you.")

The problem here is to explain why the lower copy voce has survived chain reduction (NUNES, 2011), which predicts that all links, but the head, must be deleted. According to Chomsky (2005), parallel chains may be construed starting from a single base element, when more than one uninterpretable feature probe the same item. Remember that we are considering there being an interpretive effect in cliticization, the "specificity" effect, which Machado-Rocha $(2010,2011)$ took to be the non-generic reading of $1^{\text {st }}$ and $2^{\text {nd }}$ person pronouns. The argument pronoun also must have its Case feature checked. So here we are facing a double feature checking circumstance: $[u$ Case] and $[u$ Specific], resulting in parallel chains.

In a first step, the $[u \mathrm{~N}]$ of $v$ probes the object pronoun and values the pronoun's [ $u$ Case]. This operation was assumed to occur as a long-distance checking process, with FF (Formal Features) movement, and the pronoun's matrix remaining in situ. This gives rise to the first chain:

Chain I: \{ipronoun-CaseFF, arg-licensedpronoun-matrix

But the uninterpretable features of $v$ are not exhausted yet. With the verb standardly moved to $v$, the D feature of $v$ (CHOMSKY, $1995,2000,2001)$, which is responsible for definiteness / specificity of cliticized and shifted objects, probes the same base element, the pronominal argument, whose matrix remained in situ after long-distance Case checking. Unlike the Case feature, the D feature copy operation yields a "full copy", which in turn receives a dedicated clitic form in the Morphological Component. The D-feature in $1^{\text {st }}$ and $2^{\text {nd }}$ person pronouns in BP would result in non-generic reading of these pronouns. At this point, a second chain arises:

Chain II: $\{i \mathrm{D}$-pronoun, $u \mathrm{D}$-pronoun $\}$ 
With these two chains at Spell-out, we have a doubled structure. But the question then arises: Why the tail of these chains could bypass Chain Reduction?

When we consider Chain II, there is no reason to maintain the lower copy, since they are formally the same, and the higher copy has more checked features. Chain reduction should then apply. The conditions change, when Chain I is inspected. Because there was not a full copy, but only FF copy/movement, the interpretability of the moved features depend on the chain as it is, and the lower copy must not be deleted. Because of this, both copies of the pronoun are sent to Spell-out and the doubled structure emerges.

Although this approach has its internal theoretical coherence, it poses many difficulties and requires some refinements. Among them, it would be hard to put it forward and answer why the double structure is actually required, since the single clitic structure should be able to check both Case and D-features. Besides, it is not possible to maintain the claim about interpretive effects of doubled structure, since we ended up finding some counterexamples. Consider, for instance (26):

Unambiguous reading

$A i, \quad F$, tá te tirano $\underline{\text { ocêe }}, z e ́ \ldots{ }^{7}$

There F, is 2P-CL removing you, man...

("Look at that, $\mathrm{F}$, he is mocking you, man...")

In (26), the reference of the doubled pronoun te / ocê is definite, non-generic. However, this semantic effect does not depend on the doubled structure. Either the single cliticized structure 'tá te tirano' or the non-cliticized strong pronoun structure 'tá tirano ocế' would be as much definite as the doubled one.

The opposite is also true, and we can find ambiguous structures that will not be less ambiguous if the pronoun is reduplicated:

${ }^{7}$ MACHADO-ROCHA (2013). 
(27)

Ambiguous reading between generic and definite readings Achou por bem eufazer natação e lá é Thought for good I do-INF swimming and there is

o seguinte: ou vocêfazou eles te dispensa $\underline{\boldsymbol{v o c}}^{\hat{8}}$ the following either you do or they 2P-CL dismiss you

("He thought it would be better for me to do swimming, and there this is the rule: either you do it or they dismiss you.")

What we see here is the major problem of trying to relate the previous $\mathrm{CD}$ analyses, which treat $3^{\text {rd }}$ person pronouns only, to BP data, comprised just by $1^{\text {st }}$ and $2^{\text {nd }}$ person pronouns.

If we consider $3^{\text {rd }}$ person pronouns data from previous stages of BP (or from written BP), we can parallel, for instance, the results for Spanish and BP. In this situation, BP would also restrict the use of clitic to contexts of specific / definite reference.

a. Estaprofessora, eu $\underline{a} \quad$ conheço.

This teacher I CL-ACC know

(“This teacher, I know her.")

b. * Alguma professora, eu $\underline{\boldsymbol{a}}$ conheço.

Some teacher I CL-ACC know

("Some teacher, I know her.")

But when it comes to analyze $1^{\text {st }}$ and $2^{\text {nd }}$ BP pronouns, the interpretive effect approach does not hold.

We then must go back to (26) and (27) and ask what is triggering the ambiguous readings of (27)? Notice that, unlike the definite sentence in (26), (27) has the irrealis operator "ou" (or). Curiously, even $1^{\text {st }}$ and $2^{\text {nd }}$ person BP pronouns under irrealis operators may display ambiguous readings between specific and generic. Note that in (29), the first occurrence of the clitic exhibits an unambiguously

${ }^{8}$ RAMOS (2010). 
definite reading, whereas in the second one, in which the clitic is under the scope of "se" (if), its reading is ambiguous between a definite and a generic reading.

Tô te falando pra você: se $\underline{\text { te }}$ pegarem você colando, você tá fora!

I-am 2P-CL saying to you if 2P-CL get-INF-3PL you cheating, you are out

("I'm telling you: if they get you / me / someone cheating, you / I / someone are / am / is out!")

If we consider realis sentences as "semantically unmarked", we can maintain the assumption that our clitic pronouns are intrinsically specific/definite, reconciling it with the literature. Therefore the generic reading would not lay on the clitics actually, but would be a result of sentential irrealis effect, in the presence of certain operators. There are many points to be analyzed in this respect. In BP, some tenses, like simple present and infinitive, seem to allow generic/irrealis sentences, whereas past tenses seem to disallow it. Some verbal aspects are also probably implicated in these alternations. These semantic analyses of BP clitics are, however, much beyond the scope of the present paper and we will leave it for further inquiry.

\section{Backgrounds for a new hypothesis}

From the previous analyses, an insight emerged: as everything seems to suggest, BP CD is an optional structure, in a type of freevariation with single structures. The basic structure of CD in BP is CLV-DP. Within this new analytical attempt, we will take the clitic head to be an optional Agreement head (cf. MCCLOSKEY, 1996), generated between $v$ and VP(cf. SPORTICHE (1996), CliticP/VoiceP). The core of this analysis is that this head bears only a single, bivalent but unvalued $\varphi$-feature [speaker] (ADGER, 2006). In the next sections, we review the necessary backgrounds. 


\section{Sportiche (1996): Clitic Projections}

In Sportiche's (1996) analysis, clitics are treated as functional heads possessing their own projection, the "Clitics Voices". The general structure proposed by Sportiche is as follows (p. 235):

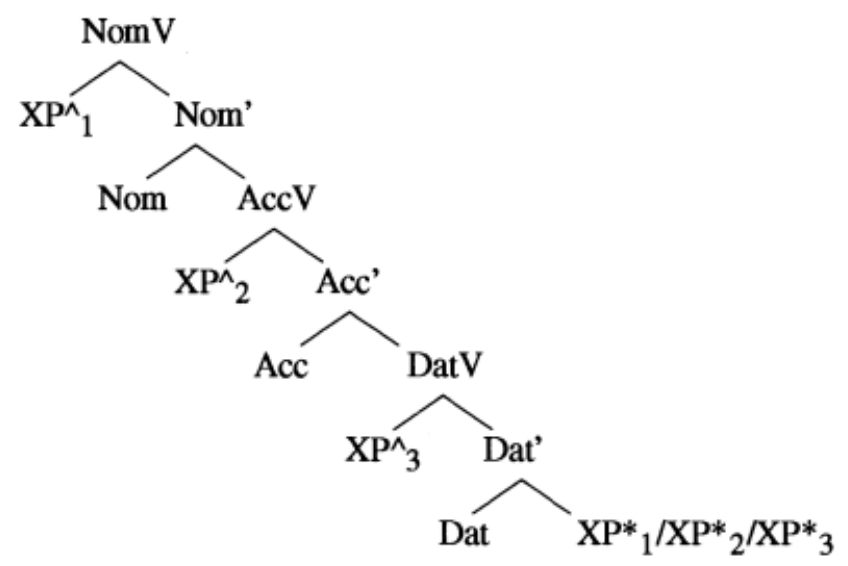

In this approach, clitic doubling and single clitic are structurally identical, and both realize an agreement relation with an argument, either a DP or an object pro. The essential difference between $\mathrm{CD}$ and SC lays on which parts of the structure are realized overtly and covertly. Every clitic $\mathrm{XP}^{\wedge}$ would be related to an argument $\mathrm{XP}^{*}$ and, at some point of the derivation (before Spell-out or at LF), $\mathrm{XP}^{*}$ must move to the clitic position $\mathrm{XP}^{\wedge}$, in order to stablish the Spec-head configuration, required by the agreement operation. One striking point of this model is that the dilemma of the base-generated vs. movement approach does not rise. Similarly, the problem of the complementary distribution of clitics and arguments, firstly discussed in Kayne (1975) disappears.

In the case of accusative arguments, the clitic would be responsible for the licensing of a specificity feature on the main XP. In what regards dative clitics, they are considered pure agreement marks, as they lack that feature. 
To motivate the movement of $\mathrm{XP}^{*}$ to $\mathrm{XP}^{\wedge}$, Sportiche aligns the movement of clitics to the general syntax of movement. To do so, he proposes the Clitic Criterion, a parallel to Rizzi's (1991) Wh-criterion (p. 236).

Wh-criterion or Q-criterion:

i. A wh- head must be in a Spec-head relationship with a wh- XP at LF.

ii. A wh- XP must be in a Spec-head relationship with a wh- head at LF.

Clitic Criterion:

i. A clitic must be in a Spec-head relationship with a $[+F] \mathrm{XP}$ at LF.

ii. $\mathrm{A}[+\mathrm{F}] \mathrm{XP}$ must be in a Spec-head relationship with a clitic at LF.

The Clitic Criterion will then be the basis for the possible clitics constructions. Sportiche also stablishes a general reading of the Clitic Criterion, which he calls the Clitic Construction parameters (p. 237):

Clitic construction parameters

i. Movement of $\mathrm{XP}^{*}$ to $\mathrm{XP}^{\wedge}$ occurs overtly or covertly.

ii. $\mathrm{H}$ is overt or covert.

iii.XP* is overt or covert.

With these generalizations at hand, it is now possible to predict a group of constructions (p. 237), which we summarize in the table below:

(43)

\begin{tabular}{|l|l|l|l|}
\hline $\mathrm{XP}^{*}$ & Movement to $\mathrm{XP}^{\wedge}$ & $\mathrm{H}$ & Resulting Construction \\
\hline covert & overtly or covertly & overt & single clitic (French, Italian, Duch) \\
\hline overt & covertly & overt & clitic doubling (Spanish, Romanian) \\
\hline overt & overtly & overt & object agreement (Lebanese Arabic) \\
\hline overt & overtly & covert & scrambling (Dutch) \\
\hline
\end{tabular}

This approach thus states that every clitic construction is in fact a doubled construction. The single clitic structure has as its DP argument a covert $\mathrm{XP}^{*}$ (an object pro), whereas the doubled 
structure has an overt DP. This analysis is also helpful in explaining the optionality of BP CD.

\section{McCloskey (1996): optional agreement head}

McCloskey (1996) proposes that Agr Projections may be intralinguistically optional, in the sense that they may be present or absent in a given derivation. This claim is made on the basis of "analytic" forms of verbs in Irish, such as in $\mathrm{xx}$, which are specified for Tense, but not for any agreement features (p. 271). Compare (xx) with (yy), in which the verb agrees regularly with the subject.

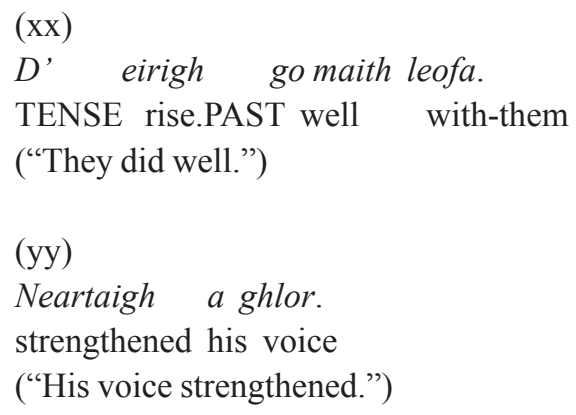

According to McCloskey, verbs in the "analytic" form, as in $(\mathrm{xx})$, being unspecified for agreement features, would not require the presence of any agreement projection. Agreement projections, in turn, have no function at LF (CHOMSKY, 1991), and so, when they do not have any syntactic function, they can be left out of the derivation. The problem for Irish is to account for the alternation between regular, agreeing verbs, and analytic impersonal verbs. The solution is drawn in (zz): 
$(\mathrm{zz})$

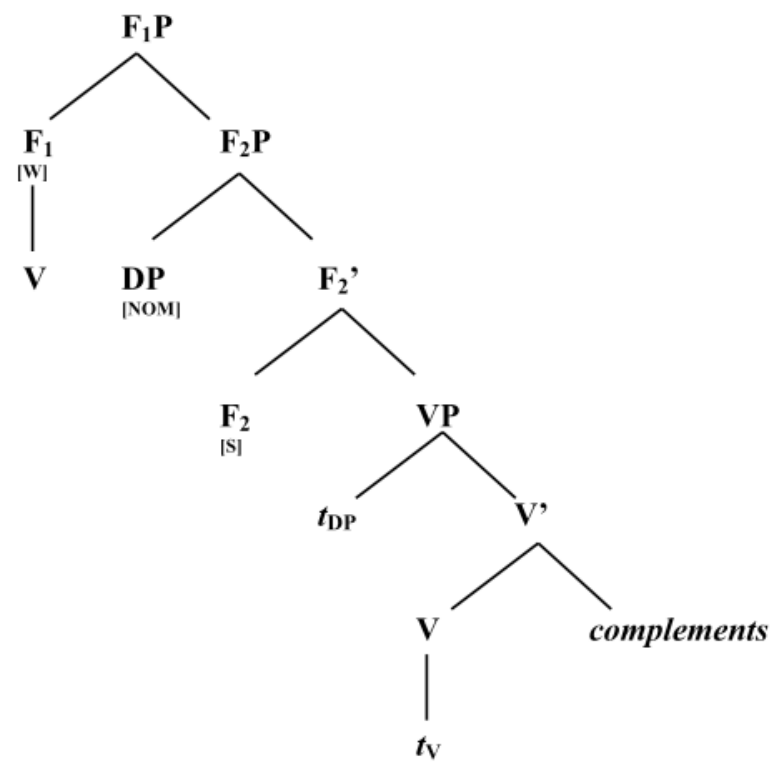

Source: MCCLOSKEY, 1996, p. 270.

In Irish, F1 would be Tense and F2, AgrP. In constructions with analytic verbs, such as in (xx), the projection F2 is dispensable, and will actually not be present. McCloskey still argues that it is a common situation that Numerations may vary. In the case of $(\mathrm{xx})$, if F2 is not selected, there will be no damage to feature-checking or interpretation. But if F2 is selected, then its own verbal and nominal features will not be checked and the derivation will crash at LF. So the conclusion is that, in these impersonal Irish constructions, only F1 is present, and F2 is left out. If, on the other hand, in the initial Numeration there is a transitive verb which sub-categorizes for a nominative noun, than F2 must also to be selected, as a requirement of convergence.

This is the optionality of agreement projections that we will claim to occur in BP clitic doubling. In section 5.1, we will discuss how the presence of the clitic projection is conditioned by the presence of a particular $\varphi$-feature, namely the unvalued feature $\left[{ }_{u}\right.$ speaker]. We 
will also argue with Adger (2006) that CD in BP is a case of pure agreement chain.

\section{Adger (2006): Features system and checking operations}

Adger's (2006) main interest is the intra-personal frequencies of morphosyntactic variants. In pursuing this goal, he reviews and readapts the minimalist model of features checking and agreement in a way which is very interesting for us.

Adger considers features to be always bivalent in nature and explains that a bivalent feature is the one which captures contrast. For instance, [singular: \pm ] is a bivalent feature and can classify pronouns as singulars and plurals.

For the pronominal system of English, he states that the features [singular: \pm ], [participant: \pm ] and [author: \pm ] are enough to generate all forms. So [singular: \pm ] would be enough to generate number variation, because this language does not have dual or further numbers neither in morphology nor in syntax. [participant: \pm ] indicates weather the pronouns refers to a participant in the speech act (speaker and addressee) or not. And [author: \pm ] (HALLE, 1997) is responsible for differentiating addressee or speaker.

The relation between the features [author: \pm ] and [participant: \pm ] are such that, having a specification for [author: \pm ] entails that [participant: \pm ] has a positive specification. And the other way round is also true: if a pronoun is specified as [participant: +], it also has to have a specification for [author: \pm ], at least in English, since there are no pronominal forms in English that do not distinguish between addressee and speaker. These observations are summarized in the Feature Co-occurrence Restriction (FCR) (p. 508):

Feature Co-occurrence Restriction (FCR)

A lexical item is specified for [participant: +] if it has a specification for [author].

With this system at hand, the featural composition of English pronoun would be as follows (p. 508): 
(45)

\begin{tabular}{c|r}
{$\left[\begin{array}{r}\text { singular:+ } \\
\text { participant:+ } \\
\text { author:+ }\end{array}\right]$ I } & {$\left[\begin{array}{r}\text { singular:- } \\
\text { participant:+ } \\
\text { author:+ }\end{array}\right]$ we } \\
\hline$\left[\begin{array}{r}\text { singular:+ } \\
\text { participant:+ } \\
\text { author:- }\end{array}\right]$ you & {$\left[\begin{array}{r}\text { singular:- } \\
\text { participant: }+ \\
\text { author:- }\end{array}\right]$ you } \\
\hline$\left[\begin{array}{r}\text { singular:+ } \\
\text { participant:- }\end{array}\right]$ he/she/it & {$\left[\begin{array}{r}\text { singular:- } \\
\text { participant:- }\end{array}\right]$ they }
\end{tabular}

In what regards agreement, the author recalls that there some features in the lexicon which are purely formal in nature: the uninterpretable features $(u)$. These features are not directly associated with semantic interpretation, but they have to be present in agreement relations with some interpretable features, or else the structure is illformed. Two generalizations state these ideas.

An agreement-chain is a pair of lexical items (LIs), where the uninterpretable features of one LI are a subset of the interpretable features of the other." (p. 509)

Full Interpretation (p. 509)

Every uninterpretable feature must be in (a lexical item in) an agreementchain."

For instance, consider

(p. 509):

*He were there. 
The problem here is related to a mismatch between the featural specification of the pronoun and the verb, because the [usingular: -] specification on were is not in an agreement-chain, and hence violates Full Interpretation.

He [singular:+, participant:-] were $[u$ singular:,$- \ldots] \ldots$

Also in BP, the features [singular: \pm ], [participant: \pm ] and [author: \pm ] will be enough to explain all pronominal forms. For our purposes, we will actually consider only the features [participant: \pm ] and [author: \pm ], since we are not dealing with plural forms. More than that, we will prefer to notate [speaker: \pm ] rather than [author: \pm ], simply to make more explicit the opposition speaker/addressee. It will also be central to our analysis the idea of agreement-chain and the checking operation of uninterpretable features as stated by Adger.

\section{Structuring the hypothesis}

We will follow Sportiche's (1996) approach in considering that clitics have their own functional projection. In BP, this projection would be generated between $v$ and $\mathrm{VP}{ }^{9}$

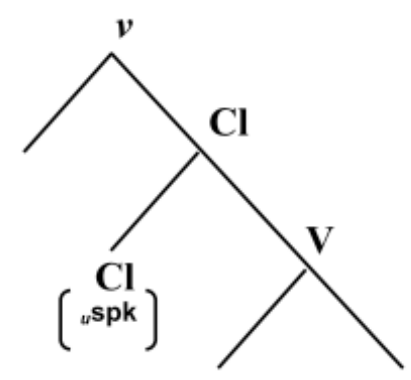

It is likewise important McCloskeys's (1996) assumption about optional agreement heads, since our clitic doubling data seem to suggest

${ }^{9}$ See Machado-Rocha (2016) for an analysis that assumes that ClP is actually above $v$. 
that BP clitics represent such an instance of optionality. And finally we have to consider that our clitic projection hosts a single, bivalent and unvalued $\varphi$-feature $\left[{ }_{u}\right.$ speaker] (ADGER, 2006).

There is some evidence that the clitics $\boldsymbol{m e}$ and te in BP do not bear more than a single person feature. For instance, we can find doubled structures with a mismatch of number features:

Ô zé, ô ta contá p'cês qui...10

Hey guy, let-me 2P-CL-Sing tell to-you-PL here...

("Hey guys, let me tell you this...")

Moreover, such structure falls under Adger's (2006) generalization presented in (46), since the ${ }_{u}$ speaker: - ] in the clitic is a subset of the richer features bundle of the pronoun ocês, with which it forms an agreement-chain.

Still based on Adger (2006), we will assume that the relevant features for the clitic forms under analysis would be as follows:

Featural composition of BP clitics $m e$ and te, and the non-attested doubling form $o$ :

[+participant, + speaker $] \quad \rightarrow$ me $\backslash 1 \mathrm{P}-\mathrm{Cl}$

[+participant, -speaker] $\rightarrow$ te $\backslash 2 \mathrm{P}-\mathrm{Cl}$

$\begin{array}{llll}\text { [-participant] } & \rightarrow \text { o } & \backslash 3 \mathrm{P}-\mathrm{Cl}\end{array}$

\section{Applying the hypothesis}

Let us firstly see how our hypothesis applies to the single clitic structure. We will illustrate it with $2^{\text {nd }}$ person pronouns; the $1^{\text {st }}$ person counterpart works pretty much the same way. Remember that according to Sportiche (1996), all object clitic structures are doubled structures, the only difference being what kind of DP is in object position: an overt DP/pronoun or an object pro. Let us resume example (12-c), renumbered here as $(53)^{11}$.

\footnotetext{
${ }^{10}$ MACHADO-ROCHA (2013).

${ }^{11}$ We will renumber all previous examples resumed below.
} 
(53)

Eu te ajudo



In (53), the merged object is a $2^{\text {nd }}$ person pro specified as [speaker: -]. This pro allows us to merge the Clitic $\mathrm{P}$ and, more than that, it requires that the CliticP is merged, since pro is not licensed directly by the verb, but needs to agree with a head bearing $\varphi$-features. When the object at stake is a pro, the absence of the clitic would generate the ungrammatical structure (12-d) "eu ajudo / I help". Remember also that, in McCloskey's (1996) analyses of unaccusatives, the "analytic" form of the verb spares the agreement projection F2, because it is specified for Tense, but not for any agreement features. When the Numeration contains, however, a transitive verb, which sub-categorizes for a nominative noun, F2 must also be selected in order for the sentence to converge. Similarly, (53) exemplifies a Numeration that contains an object pro and, consequently, requires the presence of the clitic. Once $\mathrm{CliticP}$ is merged, it enters into an Agree relation with pro and has its unvalued feature [uspeaker: \pm ] valued by the $\varphi$-features of pro as [speaker: -]. This will render the relevant clitic form, in our example, the $2^{\text {nd }}$ person clitic te.

a)

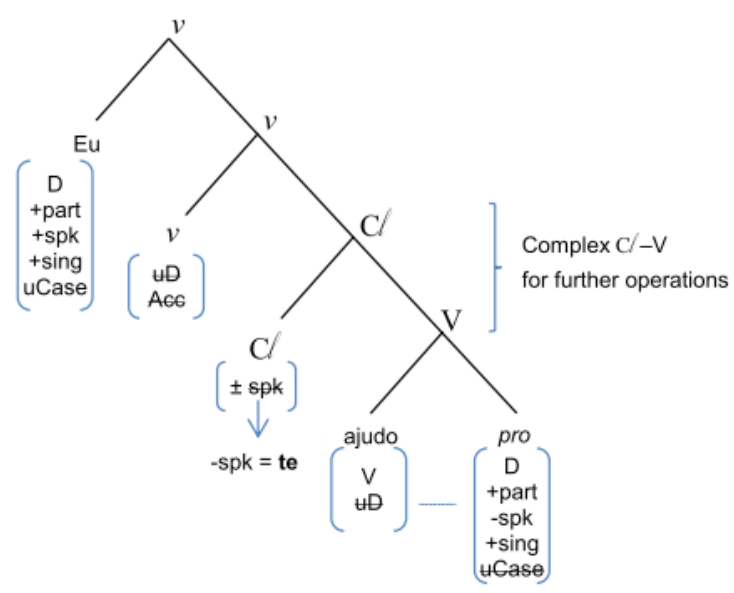


b)



c)

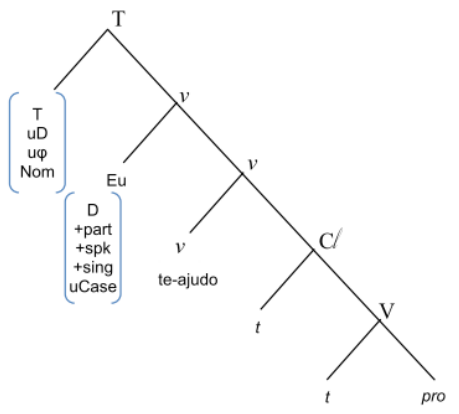

d)

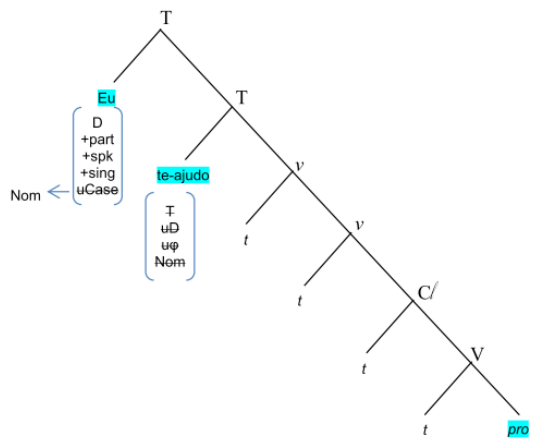


If instead of pro we merge the overt pronoun você,

Eu te ajudo você.

I 2P-CL help you

CliticP, although not required, can be merged, as there will be a potential goal for valuing the unvalued feature of this head, and we derive the doubled structure.

a)



b)




c)

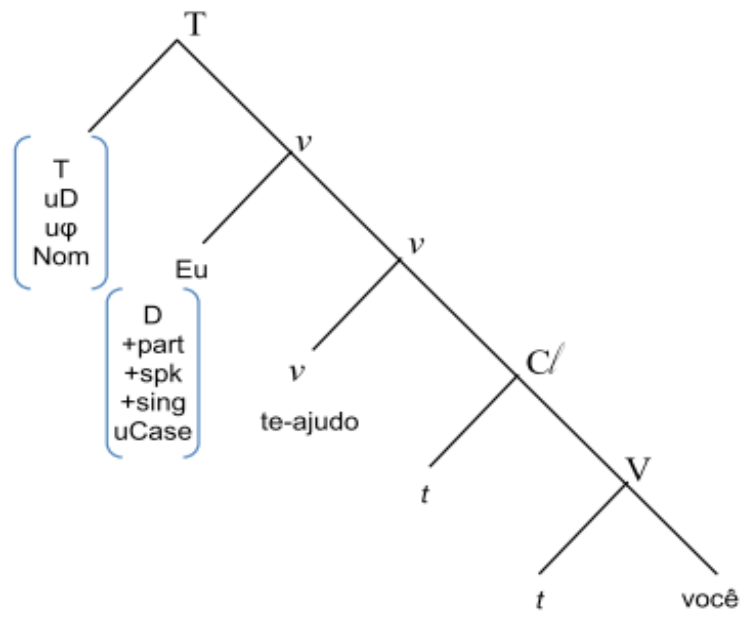

d)

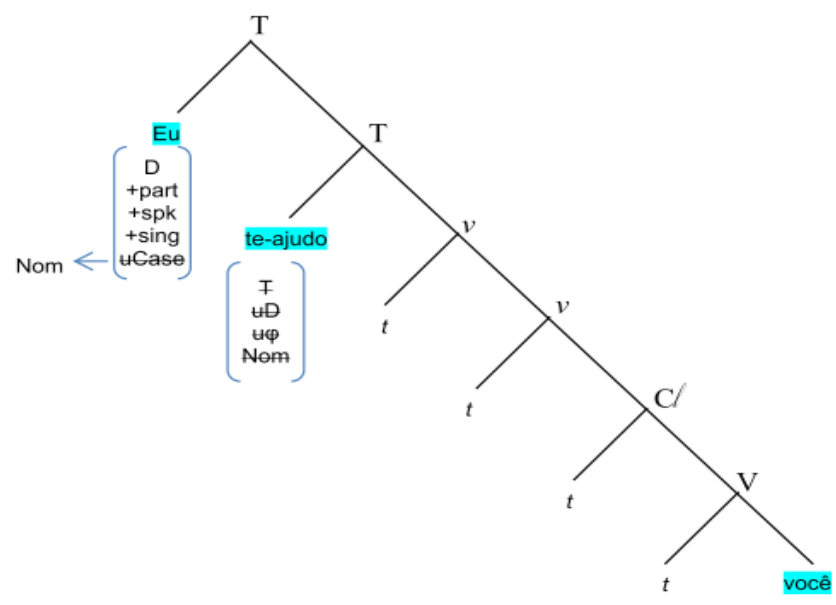

Since CliticP bears only an uninterpretable unvalued feature, its absence has no semantic effect, and it can be left out. This is the meaning of optionality of the clitic in dialectal BP data. 
(55)

Eu ajudo você.

I help you

In this case, we have the single structure with only the strong pronoun.

a)

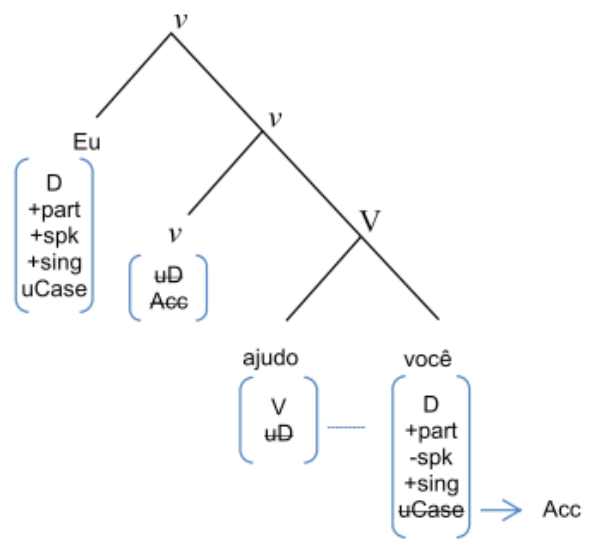

b)

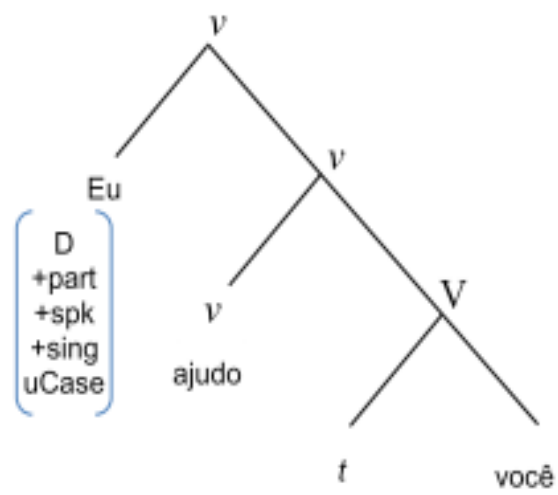


c)

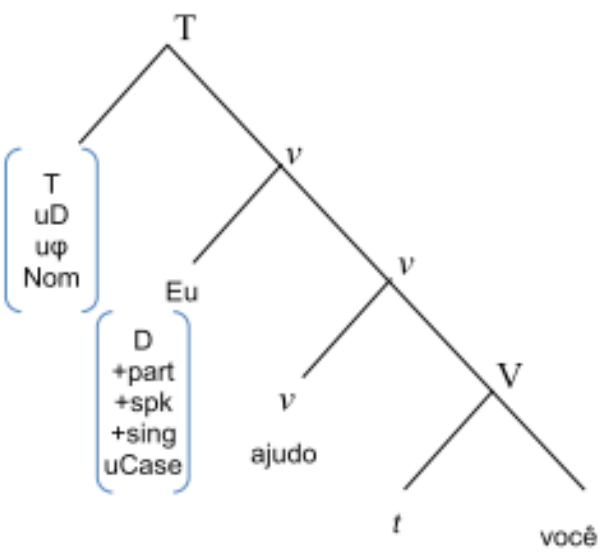

d)



Consider now that we merge the $3^{\text {rd }}$ person overt pronoun ele.

*Eu o ajudo ele

I $\underline{\text { 3P-CL help he }}$ 
As we have seen, the $3^{\text {rd }}$ person strong pronoun is underspecified for the feature [speaker]. Therefore we cannot merge CliticP, because there will be no goal for valuing the unvalued [uspeaker] feature of CliticP and the derivation will crash.

a)



The same reasoning applies if we merge a $3^{\text {rd }}$ person pro. So we have an account for the oddity of $3^{\text {rd }}$ person clitics in single structures and the ungrammaticality for the doubled structure.

\section{Eu ㅇ ajudo}

I $\underline{\text { 3P-CL }}$ help pro

a)

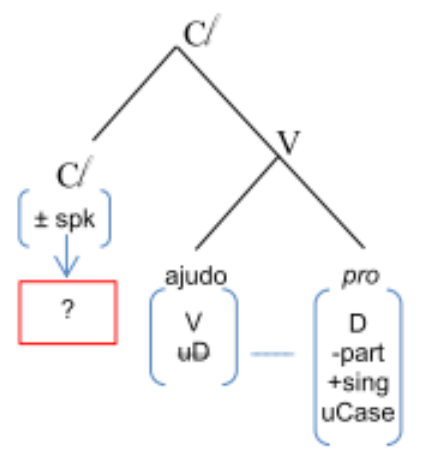


And finally, our analysis also explains why the general possible construction for $3^{\text {rd }}$ person pronominal object in spoken dialectal BP is with the overt strong pronoun, whose structure does not call for the CliticP.

Eu ajudo ele

I help $\underline{\text { he }}$

a)

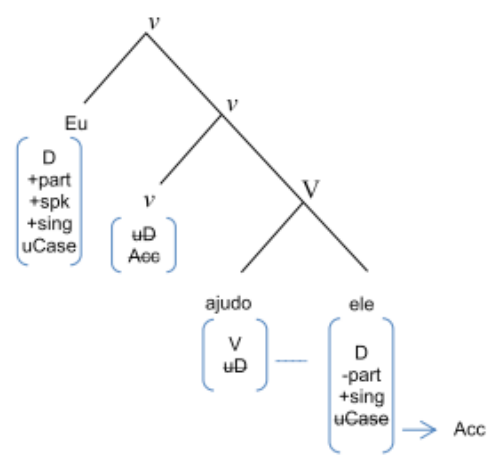

Within this hypothesis, (59) is still a puzzle:

b. Eutô te falandopra você

I am 2P-CL saying Prep you

"I am telling you (this/something)."

Usually, unvalued $\varphi$-features are not valued by objects of prepositions. This suggests that para / pra would not be a real preposition, but a case marker, correctly predicting that not all prepositions in BP allow doubling.

a. Ele conversou com você

b. *Ele te conversou com vocêe.

He talked Prep you

He 2P-CL talked Prep you

("He talked to you.") 


\section{Conclusions}

We have outlined some answers for our initial main questions.

i. Why BP CD is optional?

As we have seen, in the presence of an overt strong pronoun in the object position, the clitic projection itself is optional, since it bears only one unvalued, uninterpretable feature. This yields doubled structures (if CliticP is merged) or single structures (if CliticP is left out). If the merged objet is pro, then CliticP must be merged as a licensing requirement. This renders single structures with simple cliticization.

ii. Why BP CD occurs only for $1^{\text {st }}$ and $2^{\text {nd }}$ person pronouns?

When CliticP is merged, its unvalued [uspeaker: \pm ] feature needs to be valued against some potential goal. If the object is $1^{\text {st }}$ person, the clitic feature is valued [speaker:+]. If it is a $2^{\text {nd }}$ person, CliticP acquires [speaker:-]. Since $3^{\text {rd }}$ person pronouns are underspecified for speech-act features, being comprised basically by [participant:-], the clitic projection cannot be merged. If it is, the unvalued uninterpretable feature leads the derivation to crash.

The idea of a head bearing just uninterpretable phi-features is contra Chomsky's (1995) theoretical argument against AgrP. However, one might weaken this argument to one that suggests that heads bearing just uninterpretable features are not theoretically ruled out, but rather diachronically unstable. For the case of BP, this would appear to be right and to correlate with a gradual loss of featural richness in the pronominal system (cf. NUNES 2008, 2011).

In this sense, the clitic doubling structure in Brazilian Portuguese is a pure agreement chain, not directly related to any interpretive effect. According to Adger (2006, p. 508), "these purely formal features are not associated with a semantic interpretation directly, but they have to be in an agreement relation with semantically interpreted features, or else the structure is ill-formed". This is quite true for the case of pro objects. But the situation in BP is even more delicate, since the scenario of variation in this language shows a transition from the preference for the single clitic structure (like most of Romance languages) to one in which the strong 
pronoun (with no clitic) is preferred. But what is found now is the use of both structures and plus the doubled structure. These puzzling topics are still open for further research.

\section{References}

ADGER, D. Combinatorial Variability. Journal of Linguistics, Cambridge, v. 42, n. 3, p. 503-530, 2006.

ANAGNOSTOPOULOU, E. Clitic Dependencies in Modern Greek. 1994. Thesis. (PhD) - Salzburg University, Salzburg, Austria, 1994.

. The Syntax of Ditransitives: Evidence from Clitics. Berlin / New York: Mouton de Gruyter, 2003.

. Clitic Doubling. In: EVERAERT, M.; RIEMSDIJK, H. (Ed.) The Blackwell Companion to Syntax, v. 1, chap. 14, p. 519-581. Oxford: Blackwell Publishing, 2006.

BLEAM, T. Leísta Spanish and the Syntax of Clitic Doubling. 1999. Thesis (PhD) - University of Delaware, Newark, DE, U.S., 1999.

BORER, H. Parametric Syntax: Case Studies in Semitic and Romance Languages. Dordrecht: Foris, 1984.

http://dx.doi.org/10.1515/9783110808506

BURZIO, L. Italian Syntax. Dordrecht: Kluwer, 1986.

CARVALHO, D. A estrutura interna dos pronomes pessoais em português. 2008. Tese (Doutorado em Linguística) - Universidade Federal de Alagoas, Maceió, AL, 2008.

CASTILHO, C. M. M. O processo de redobramento sintático no português medieval. 2005. Tese (Doutorado em Linguística) - Instituto de Estudos da Linguagem, Universidade Estadual de Campinas, Campinas, SP, 2005.

CHOMSKY, N. Barriers (Linguistic Inquiry Monograph 13), Cambridge, MA: MIT Press, 1986.

. Some notes on economy of derivation and representation. In: Freidin, R. (Ed.). Principles and Parameters in Comparative Grammar. Cambridge, MA: MIT Press, 1991. p. 417-54.

. A minimalist program for linguistic theory. In: HALE, K.; KEYSER, S. J. (Ed.) The View from Building 20. Cambridge, MA: MIT Press, 1993, p. 1-52. 
. The Minimalist Program. Cambridge, MA: The MIT Press, 1995. Minimalist Inquiries: The framework. In: MARTIN, R.; MICHAELS, D.; URIAGEREKA, J. (Ed.) Step by Step: Essays on minimalist syntax in honor of Howard Lasnik. Cambridge, MA: MIT Press, 2000. p. 89-155.

. Derivation by Phase. In: KENSTOWICZ, M. (Ed.). Ken Hale: A Life in Language. Cambridge, MA: MIT Press, 2001.

. On Phases. Cambridge, MA: MIT, 2005.

CORRÊA, V. O objeto nulo no português do Brasil. 1991. Dissertação (Mestrado em Linguística) - Instituto de Estudos da Linguagem, Universidade Estadual de Campinas, Campinas, SP, 1991.

DOBROVIE-SORIN, C. Clitic Doubling, Wh-Movement, and Quantification in Romanian. Linguistic Inquiry, v. 21, p. 351-397, 1990.

DUFFIELD, N. Particles and projections. 1991. Thesis - University of Southern California, CA, U.S., 1991.

. A sintaxe pronominal do Português Brasileiro e a tipologia dos pronomes. In: GALVES, C. M. C. Ensaios sobre as gramáticas do Português. Campinas, SP: UNICAMP, 2001.

GROAT, E. English Expletives: A Minimalist Approach. Linguistic Inquiry, v. 26, p. 354-365, 1995.

HALLE, M.; MARANTZ, A. Distributed Morphology and the Pieces of Inflection. In: HALE, K.; KEYSER, J. (Ed.) The View from Building 20. Cambridge, MA: MIT Press, 1993. p. 111-176.

HALLE, M. Distributed Morphology: impoverishment and fission. MIT Working Papers in Linguistics, v. 30, p. 425-449, 1997.

JAEGGLI, O. Topics in Romance Syntax. Dordrecht: Foris, 1982.

. Three Issues in the Theory of Clitics: Case, Doubled NPs and Extraction. In: BORER, H. (Ed.). The Syntax of Pronominal Clitics. New York: Academic Press, 1986. p. 15-42.

KATO, M. A gramática do letrado: questões para a teoria gramatical. In: MARQUES, M.A.; KOLLER, E.; TEIXEIRA, J.; LEMOS, A. S. (Org.). Ciência da linguagem: trinta anos de investigação e ensino. Braga: CEHUM (Universidade do Minho), 2005. p. 131-245.

KAYNE, R. French Syntax. Cambridge, MA: MIT Press, 1975. 
MACHADO-ROCHA, R. Morfossintaxe de caso nos pronomes pessoais do PB/MG atual. Dissertação (Mestrado em Linguística) - Faculdade de Letras, Universidade Federal de Minas Gerais, Belo Horizonte, 2010.

. A reanálise dos clíticos me e te em estruturas de redobro pronominal no dialeto mineiro. Caligrama, Belo Horizonte, UFMG, v. 16, p. 105-129, 2011.

. Spontaneous speech - High school students from Belo Horizonte. 2013. Unpublished corpus.

. O redobro de clítico no português brasileiro dialetal. 2016. Tese (Doutorado em Linguística) - Universidade Federal de Minas Gerais, Belo Horizonte, MG, 2016.

MAGALHÃES, T. Aprendendo o sujeito nulo na escola. 2000. Dissertação (Mestrado em Linguística) - Instituto de Estudos da Linguagem, Universidade Estadual de Campinas, Campinas, SP, 2000.

MCCLOSKEY, J. Clause structure, ellipsis and proper government in Irish. Lingua, v. 85, p. 259-302, 1991.

. Subjects and Subject Positions in Irish. In: BORSLEY, R.; ROBERTS, I. (Ed.) The Syntax of The Celtic Languages: A Comparative Perspective. New York: Cambridge University Press, 1996. p. 241-283.

NUNES, J. Inherent Case as a Licensing Condition for A-movement: The Case of Hyper-raising Constructions in Brazilian Portuguese. Journal of Portuguese Linguistics, v. 7, p. 83-108, 2008.

NUNES, J. The Copy Theory. In: BOECKX, C. (Ed.). The Oxford Handbook of Linguistic Minimalism. Oxford: Oxford University Press, 2011. p. 143-172.

RAMOS, J. M. Corpus do dialeto mineiro: textos orais; textos escritos dos séculos XVIII, XIX e XX. Belo Horizonte: UFMG / FAPEMIG / CNPq / Núcleo de Pesquisa em Variação Linguística, 2010. (Electronic Version).

RIZZI, L. Residual verb-second and the wh-criterion. Unpublished MS, Université de Genève, 1991.

ROBERTS, I. Agreement and head movement: clitics, incorporation, and defective goals. Cambridge, MA: The MIT Press, 2010.

SPORTICHE, D. Clitic Constructions. In: ROORYCK, J.; ZARING, L. (Ed.) Phrase Structure and the Lexicon. Dordrecht: Kluwer, 1996. p. 213-276. 
SUÑER, M. The Role of Agreement in Clitic-Doubled Constructions. Natural Language and Linguistic Theory, v. 6, p. 391-434, 1988.

TORREGO, E. On the nature of clitic doubling. In: CAMPOS, H.; KEMPCHINSKY, P. M. (Ed.) Evolution and Revolution in Linguistic Theory. Washington: Georgetown University Press, 1995. p. 399-418. . The Dependencies of Objects. Cambridge, MA: MIT Press, 1998. URIAGEREKA, J. Aspects of the Syntax of Clitic Placement in Western Romance. Linguistic Inquiry, v. 26, p. 79-124, 1995. 